\title{
Plasma Electrolytic Oxidation Treatment of Zr-2.5\%Nb Alloy for Corrosion Resistance Enhancement
}

\author{
ELISABETA COACA ${ }^{1,2}$, ALEXANDRU MARIN ${ }^{1 *}$, OANA RUSU ${ }^{1}$, VIOREL MALINOVSCHI ${ }^{3}$, VICTOR ANDREI ${ }^{4}$ \\ IInstitute for Nuclear Research Pitesti, 1 Campului Str., Mioveni, Arges, Romania \\ 2Politehnica University of Bucharest, Physical Chemistry and Electrochemistry, Department of Inorganic Chemistry, 132 Calea \\ Grivitei, 010737, Bucharest, Romania \\ 3University of Pitesti, 1 Targul din Vale Str., 110040, Pitesti, Romania \\ 4ELSSA Laboratory SRL, 26 Crinului Str., 110109, Pitesti, Romania
}

\begin{abstract}
Anticorrosion layers were prepared on commercial Zr-2.5\% Nb alloy by employing plasma electrolytic oxidation (PEO) process in aqueous electrolyte solutions. Microstructure and electrochemical behavior were evaluated using X-ray diffraction (XRD), optical metallography and potentiodynamic polarization measurements. The obtained coatings are uneven, presenting a dominant monoclinic crystallographic phase of $\mathrm{ZrO}$, Enhanced corrosion resistance was attributed to the PEO-treated samples compared to the commercial black oxide coating.
\end{abstract}

Keywords: plasma electrolytic oxidation, zirconium oxide, $\mathrm{Zr}-2.5 \% \mathrm{Nb}$ alloy, tetrasodium pyrophosphate, sodium silicate

Although zirconium-based alloys are used in nuclear industry due to their low neutron absorption cross-section and favorable mechanical and electrochemical properties, enhanced oxidation and hydration chemical processes occur due to tremendous operating conditions found in water-cooled nuclear reactor environment [1-9]. In the case of nuclear pressure tubes made from Zr-2.5\%Nb alloy, the black oxide layer formed on this commercial alloy protects the surface against oxidation and corrosion at high temperatures during in-reactor operation [10]. However, plasma electrolytic oxidation (PEO) coatings attracted attention in the last decade regarding the improvement of wear and corrosion resistance of zirconium nuclear alloys by growing $\mathrm{ZrO}_{2}$ protective layers during electrochemical oxidation of metal surfaces [11, 12]. Additionally, taking into account the limited available literature on PEO-treated Zr alloys, including Zy-2 [13, 14], Zy-4 [15, 16], Zr-1\%Nb $[17,18]$ and $\mathrm{Zr}-2.5 \% \mathrm{Nb}[19,20]$, further work will be required to optimize and improve the coating layers in the approach of material-coolant interaction.

This paper assesses the enhanced anti-corrosion behavior of commercial $\mathrm{Zr}-2.5 \% \mathrm{Nb}$ alloy. The purchased CANDU pressure tubes are always covered with a black oxide film obtained by autoclaving. We propose to prepare additional ceramic films based on ZrO (zirconia) generated onto the surface of existing black oxide layer. For this, plasma electrolytic oxidation is performed by using $\mathrm{Na}_{4} \mathrm{P}_{2} \mathrm{O}_{7}$ and $\mathrm{Na}_{2} \mathrm{SiO}_{3}$ aqueous electrolytes. Then, the $\mathrm{ZrO}_{2}$ films are characterized by X-ray diffraction, metallography of their cross-section and potentiodynamic polarization curves in $\mathrm{LiOH}$ aqueous solution.

\section{Experimental part}

Plasma electrolytic oxidation process was performed on samples cut out of a commercial Zr-2.5\%Nb CANDU pressure tube without mechanically removing the initial black oxide coating, in order to probe another deposition approach as compared to our previous work [12].

Prior to PEO oxidation treatment, the substrates were ultrasonically cleaned in ethyl alcohol and acetone for 10 $\mathrm{min}$. The samples were divided into two groups according to the electrolytic environment for PEO process (table 1). The compositions of the aqueous electrolyte solutions consist of $10 \mathrm{~g} / \mathrm{L} \mathrm{Na} \mathrm{P}_{2} \mathrm{O}_{2}+2 \mathrm{~g} / \mathrm{L} \mathrm{KOH}$ (E1 electrolyte) and $10 \mathrm{~g} / \mathrm{L} \mathrm{Na} \mathrm{P}_{2} \mathrm{O}_{7}+10^{2} \mathrm{~g} / \mathrm{L} \mathrm{Na} \mathrm{SiO}_{3} \cdot 5 \mathrm{H}_{2} \mathrm{O}$ (E2 electrolyte), respectively. A pulsed unipolar pow er supply with $150 \mathrm{~Hz}$ frequency was employed in a constant voltage regime [21]. A full description of the preparation method was described elsewhere [12]. Table 1 shows the sample codes, applied voltage $(U)$ and PEO process time $(\tau)$ in E1 and E2 electrolytes.

Microstructure of the deposited PEO coatings has been studied by X-ray diffraction and optical metallography and the corrosion behavior was evaluated using potentiodynamic polarization curves.

The diffraction patterns were recorded in a parallel beam geometry using a Rigaku Ultima IV diffractometer equipped with a Cross Beam Optics system and a high precision vertical goniometer $(\theta-\theta)$ with $285 \mathrm{~mm}$ radius. A CuK $\alpha$ radiation source operated at $40 \mathrm{kV}$ and $40 \mathrm{~mA}$ was used. The samples were scanned from 10 to $80^{\circ}(2 \theta)$ in steps of $\Delta(2 \theta)=0.05^{\circ}$ and $4 \mathrm{~s}$ step time.

\begin{tabular}{|c|c|c|c|}
\hline Sample code & $\begin{array}{c}\mathrm{U} \\
\text { (V) }\end{array}$ & $\begin{array}{c}\tau \\
(\min )\end{array}$ & Electrolyte aqueous solutions \\
\hline $\begin{array}{c}\mathrm{AC} \\
\text { (commercial, autoclaved } \\
\mathrm{Zr}-2.5 \% \mathrm{Nb} \text {, as reference } \\
\text { sample) }\end{array}$ & - & - & - \\
\hline M1 & 200 & 5 & \multirow[t]{2}{*}{ EI: $10 \mathrm{~g} / \mathrm{L} \mathrm{Na4} \mathrm{P}_{2} \mathrm{O}_{7}+2 \mathrm{~g} / \mathrm{L} \mathrm{KOH}$} \\
\hline $\mathrm{M} 2$ & 200 & 20 & \\
\hline$\overline{M B}$ & 300 & 10 & \multirow[t]{2}{*}{$E 2: 10 \mathrm{~g} / \mathrm{L} \mathrm{Na}{ }_{4} \mathrm{P}_{2} \mathrm{O}_{7}+10 \mathrm{~g} / \mathrm{L} \mathrm{Na}_{2} \mathrm{SiO}_{3} \cdot 5 \mathrm{H}_{2} \mathrm{O}$} \\
\hline $\mathrm{M4}$ & 200 & 30 & \\
\hline
\end{tabular}

Table 1

SAMPLE CODES AND PLASMA ELECTROLYTIC OXIDATION OPERATING CONDITIONS IN E1 AND E2 ELECTROLYTES

*email marin.alexandru.horia@gmail.com; Phone: 0040742143141 
An Olympus GX71 optical microscope was employed to observe the multilayered structure of the PEO coatings. The samples were prepared by cutting strips using a diamond saw (Isomet4000) and embedding them in thermosetting resin with the METAPRESS-A (Metkon) mounting press. The mechanical cleaning process including grinding and polishing was performed with abrasive papers of 1200 and $2400-4000$ grits, respectively. The chemical attack solution contains $45 \% \mathrm{HNO}_{3}, 10 \% \mathrm{HF}$ and $45 \%$ demineralized water.

The corrosion resistance of the oxide coatings was assessed by potentiodynamic polarization measurements carried out on a PARSTAT-2273 potentiostat/galvanostat (Advanced Electrochemical System, Princeton Applied Research) in a three-electrode set-up, including the working electrode (tested sample), a platinum counterelectrode and a saturated calomel reference electrode $\left(0.244 \mathrm{~V}\right.$ vs. SHE at $\left.25^{\circ} \mathrm{C}\right)$. Polarization curves were recorded at a scan rate of $2 \mathrm{mV} / \mathrm{s}$, starting from -0.5 $\mathrm{V}$ to $+2 \mathrm{~V}$, in an $0.2 \mathrm{M} \mathrm{LiOH}$ aqueous solution.

\section{Results and discussions}

Figure 1 shows the XRD patterns of all the PEO-treated samples along with the autoclaved substrate indicating the presence of monoclinic $\mathrm{ZrO}$ (JCPDS 88-2390), tetragonal $\mathrm{ZrO}_{2}$ (J CPDS 88-1007) and $\alpha-Z r$ polycrystalline phases (JCPDS 89-3045).
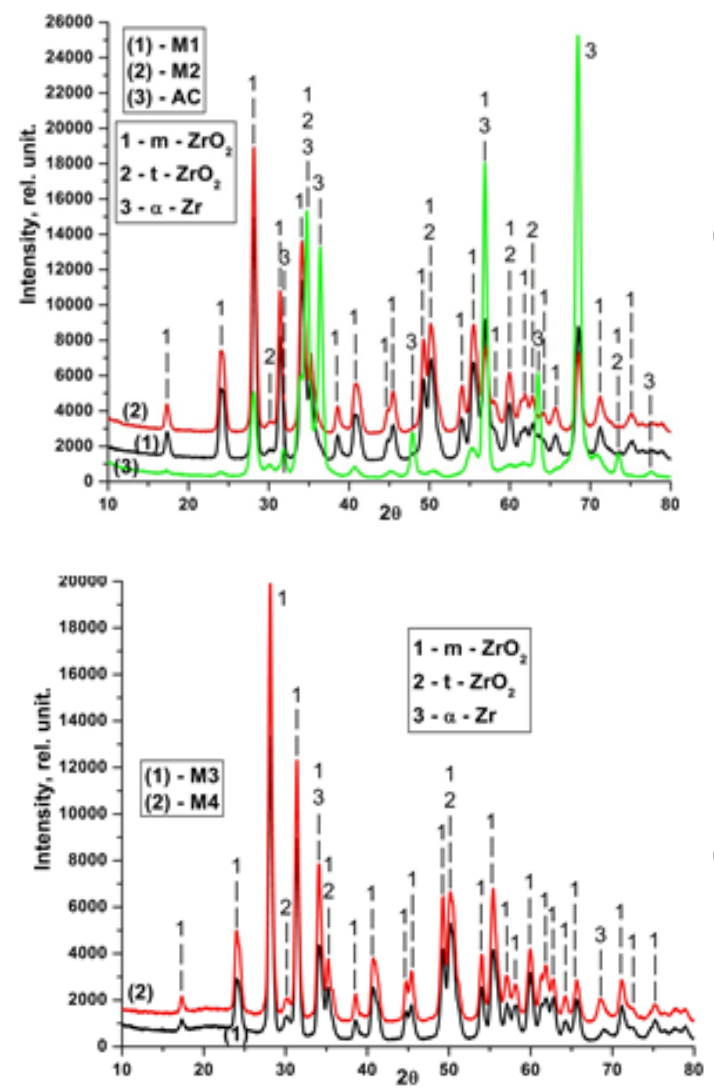

Fig. 1. X-ray diffraction patterns of non-treated sample (AC) and PEO coatings formed in: (a) E1 electrolyte (M1 and M2 samples);

(b) E2 electrolyte (M3 and M4 samples)

By applying Toraya method [22], the monoclinic and tetragonal phase volumes of zirconia were estimated. In order to do this, volume fraction of $m-\mathrm{ZrO}_{2}\left(\mathrm{~V}_{\mathrm{m}}\right)$ can be calculated using the equation (1):

$$
V_{m}=\frac{1.311 \cdot X_{m}}{I_{m}+0.311 \cdot X_{m}}
$$

where $X_{m}$ has an expression:

$$
X_{m}=\frac{I_{m}(-111)+I_{m}(111)}{I_{m}(-111)+I_{m}(111)+I_{t}(101)} \text {, and } I(h k l) \text { are the }
$$

integrated experimental intensities in the diffraction patterns for different orientation planes.

Also, the volumic fraction of t-ZrO ${ }_{2}$ phase was estimated from the equation:

$$
V_{t}=1-V_{m}
$$

For this purpose, the diffraction lines (-111) and (111) of monoclinic $\mathrm{ZrO}_{2}$ and diffraction line (101) of tetragonal $\mathrm{ZrO}_{2}$, respectively, were successfully indexed and the calculated integrated intensities were refined using the pseudo-Voigt analytical function. The obtained integrated intensities have been used to estimate $\mathrm{m}-\mathrm{ZrO}$ and $\mathrm{t}-\mathrm{ZrO}{ }_{2}$ phase volume fractions involving equations (1) and (2) [12].

From table 2, it can be seen a dominant monoclinic $\mathrm{ZrO}$, phase ( $\sim 97 \%)$ associated with an inhibited tetragonal phase of zirconia $(\sim 3 \%)$, totally in contrast to our previous results reported in [12] where either $\mathrm{NaAlO}_{2}(\mathrm{pH}=13.0)$ or $\mathrm{NaAlO}$ and $\mathrm{NaOH}(\mathrm{pH}=13.2$ ) aqueous solutions were used in PEO process. Although identical potentiostatic operating regime was used, crystallographic phase modifications occur and could be related to the substrate surface chemistry or the chemical nature of electrolytic solution employed. However, it is interesting to note that changing the electrolyte environment has no strong influence on the crystallographic behavior of $\mathrm{ZrO}_{2}$ coating on $\mathrm{Zr}-2.5 \% \mathrm{Nb}$ alloy, as evidenced in table 2 .

\section{Table 2}

MONOCLINIC TO TETRAGONAL PHASE RATIOS (VOL. \%)

\begin{tabular}{|c|c|c|}
\hline \multirow{2}{*}{ Sample code } & \multicolumn{2}{|c|}{ Volumic percentages } \\
\hline & $\mathrm{m}-\mathrm{ZrO}_{2}$ & $\mathrm{t}-\mathrm{ZrO}_{2}$ \\
\hline M1 & 97.4 & 2.6 \\
\hline $\mathrm{M} 2$ & 97.3 & 2.7 \\
\hline $\mathrm{M} 3$ & 96.0 & 4.0 \\
\hline $\mathrm{M4}$ & 97.0 & 3.0 \\
\hline
\end{tabular}
OF POLYCRYSTALLINE ZIRCONIA CALCULATED FROM TORAYA'S EQUATION

Figure 2 displays the optical examination of the PEOtreated alloys revealing the layered structure of the coatings. It can be seen that a bi-layered coating was obtained on $\mathrm{Zr}-2.5 \% \mathrm{Nb}$ alloy during electrolytic oxidation in E1 electrolyte solution (figs. 2a,b). The layers thicknesses increased with the increase of treatment time for the same electrolytic bath composition. Notably, a different behavior was observed after electrolysis process of $Z r$ alloy in E2 electrolyte (figs. 2c,d). The influence of deposition time on film growth was illustrated by a three-layered structure (fig. 2d). Apparently, although the coating is found to possess a larger thickness after a longer period of deposition, the total layer thickness generated in E2 electrolyte was approximately the same for both samples (fig. 2c,d). However, a contribution of commercial black oxide layer cannot be ruled out.

The experimental potentiodynamic polarization curves for commercial $\mathrm{Zr}-2.5 \% \mathrm{Nb}$ alloy, M1, M2, M3 and M4 samples were shown in figure 3 . Table 2 summarizes calculated values of corrosion potential $\left(\mathrm{E}_{\text {cor }}\right)$, corrosion current density $\left(\mathrm{j}_{\mathrm{for}}\right)$ and corrosion rates $\left(\mathrm{V}_{\text {corr }}\right.$ ) for the nontreated and PEO-treated samples. ${ }^{\text {cor The }}$ above electrochemical parameters were estimated by Tafel method with PowerSuite corrosion analysis software.

Table 3 shows the key measurements regarding the corrosion resistance of M1, M2, M3 and M4 PEO coatings as compared to $\mathrm{Zr}-2.5 \% \mathrm{Nb}$ covered with black oxide. As can be seen, the corrosion current density of the black oxide coating is about $94 \times 10^{-3} \mu \mathrm{A} / \mathrm{cm}^{2}$, a value with one 


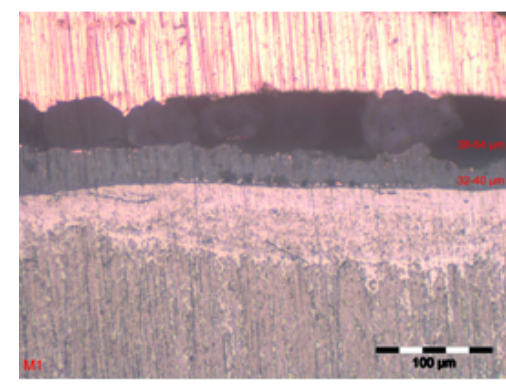

(a)

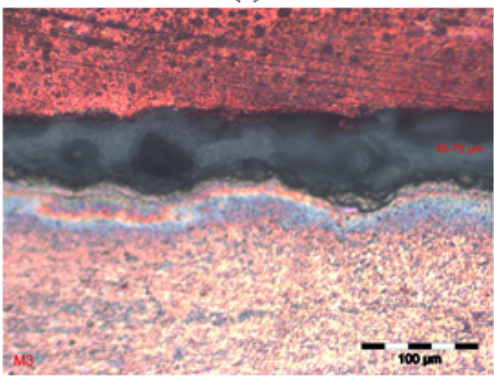

(c)

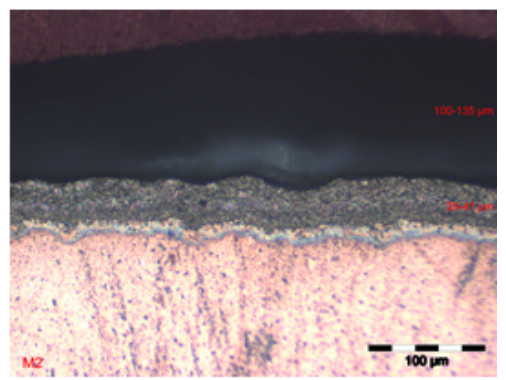

(b)

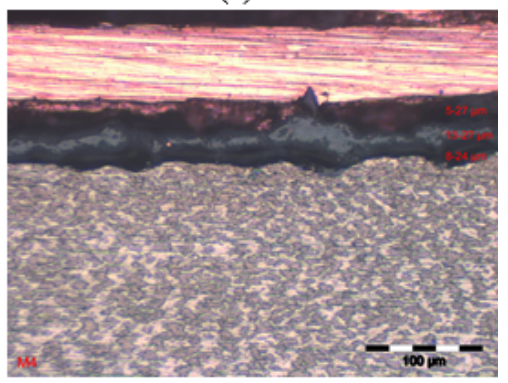

(d)

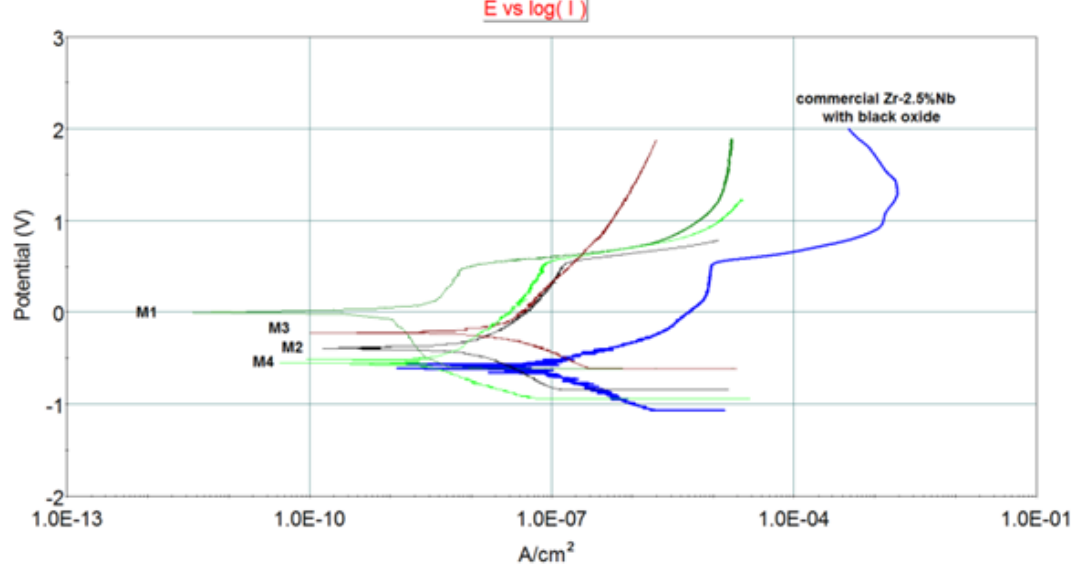

$\mathrm{A} / \mathrm{cm}^{2}$

\begin{tabular}{|c|c|c|c|}
\hline $\begin{array}{c}\text { Sample } \\
\text { code }\end{array}$ & $\begin{array}{c}\mathbf{E}_{\text {corr }} \\
(\mathbf{m V})\end{array}$ & $\begin{array}{c}\mathbf{j}_{\text {corr }} \times 10^{4} \\
\left(\boldsymbol{\mu A} / \mathbf{c m}^{2}\right)\end{array}$ & $\begin{array}{c}V_{\text {corr }} \times \mathbf{1 0} \\
(\mathbf{m m} / \text { year })\end{array}$ \\
\hline $\begin{array}{c}\text { Commercial, autoclaved } \\
\text { Zr-2.5\%Nb } \\
\text { covered with black oxide }\end{array}$ & -608 & 940 & 210 \\
\hline $\mathrm{M1}$ & -2 & 8.4 & 1.55 \\
\hline $\mathrm{M} 2$ & -380 & 21 & 4.02 \\
\hline $\mathrm{M}$ & -220 & 36 & 8.94 \\
\hline $\mathrm{M}$ & -515 & 16 & 3.97 \\
\hline
\end{tabular}

order of magnitude higher then plasma electrolytic oxidized samples indicating an increased corrosion protection for all PEO-treated samples. Moreover, M1 sample yielded best corrosion resistance showing that the corrosion current density decreased with two orders of magnitude as compared to the commercial $\mathrm{Zr}-2.5 \% \mathrm{Nb}$ alloy. One possible explanation for this outcome could be the formation of a more compact and dense structure of about $100 \mu \mathrm{m}$ thickness layer observed onto the surface during E1 electrolyte deposition, confirmed by metallographic measurements (fig. 2a).

\section{Conclusions}

Using constant voltage deposition regime, the ZrO films were prepared on commercial autoclaved $\mathrm{Zr}-2.5 \% \mathrm{Nb}$ alloy (covered with black oxide) from two aqueous electrolytes: $10 \mathrm{~g} / \mathrm{L} \mathrm{Na} \mathrm{P}_{2} \mathrm{O}_{7}+2 \mathrm{~g} / \mathrm{L} \mathrm{KOH}$ and $10 \mathrm{~g} / \mathrm{L} \mathrm{Na}_{4} \mathrm{P}_{2} \mathrm{O}_{7}+10 \mathrm{~g} / \mathrm{L}$ $\mathrm{Na}_{2} \mathrm{SiO}_{3} \cdot 5 \mathrm{H}_{2} \mathrm{O}$ by means of plasma electrolytic oxidation. The coating layers are uneven, possessing thicknesses between 75-175 $\mu \mathrm{m}$, depending on the employed electrolyte. XRD patterns indicated the presence of both
Fig. 2. Cross-section metallographic images of the PEO prepared coatings. Samples from

E1 electrolyte: (a) M1; (b) M2. Samples from E2 electrolyte: (c) M3; (d) M4
Fig. 3. Potentiodynamic polarization curves of commercial $\mathrm{Zr}-2.5 \% \mathrm{Nb}$ with black oxide, M1, M2, M3 and M4 samples
Table 3

CORROSION PARAMETERS OF COMMERCIAL AUTOCLAVED Zr-2.5\%Nb ALLOY AND M1, M2, M3, M4 SAMPLES IN 0.2 M LIOH SOLUTION monoclinic and tetragonal phase of zirconium oxide, the monoclinic zirconia being a dominant phase. The layered structure of the coatings illustrated by cross-section metallographic images was influenced by the deposition time.

However, all coatings exhibit increased corrosion resistance with one order of magnitude higher than the autoclaved $\mathrm{Zr}-2.5 \% \mathrm{Nb}$ alloy while M1 sample (PEO prepared from $10 \mathrm{~g} / \mathrm{L} \mathrm{Na}{ }_{4} \mathrm{P}_{2} \mathrm{O}_{7}+2 \mathrm{~g} / \mathrm{L} \mathrm{KOH}, 200 \mathrm{~V}, 5 \mathrm{~min}$ ) presents a two order of magnitude increase in corrosion protection compared to the black oxide. Both electrolytic environments favor corrosion protection of $\mathrm{Zr}-2.5 \% \mathrm{Nb}$ alloy.

\section{References}

1. HOLT, R.A., Journal of Nuclear Materials, 372, 2008, p. 182-214.

2. WARR, B.D., ELMOSELHI, M.B., NEWCOMB, S.B., MCINTYRE, N.S., BRENNENSTUHL, A.M., LICHTENBERGER, P.C., Oxide Characteristics and Their Relationship to Hydrogen Uptake in Zirconium Alloys, in: Zirconium in the Nuclear Industry: Ninth Int. Symp., ASTM STP 1132, C.M. Eucken (Ed.), ASTM, Philadelphia, 1991, p. 740-757. 
3. NORTHWOOD, D., MENG-BURANY, X., WARR, B.D., Microstructure of Zr-2.5 Nb Alloy Pressure Tubing, in: Zirconium in the Nuclear Industry: Ninth Int. Symp., ASTM STP 1132, C.M. Eucken (Ed.), ASTM, Philadelphia, 1991, p. 156-172.

4. COX, B., J ournal of Nuclear Materials, 336, no. 2-3, 2005, p. 331-368. 5. CHRISTODOULOU, N., CAUSEY, A.R., HOLT, R.A., TOMÉ, C.N., BADIE, N., KLASSEN, R.J ., SAUVÉ, R., W 00, C.H., Modeling in-Reactor Deformation of Zr-2.5 Nb Pressure Tubes in CANDU Power Reactors, in: Zirconium in the Nuclear Industry, Eleventh Int. Symp., ASTM STP 1295, E.R. Bradley, G.P. Sabol (Eds.), ASTM, Philadelphia, 1996, p. 518537.

6. KUMAR, M.K., AGGARWAL, S., KAIN, V., SAARIO, T., BOJ INOV, M., Nuclear Engineering and Design, 240, no. 5, 2010, p. 985-994.

7. MAROTO, A.J.G., BORDONI, R., VILLEGAS, M., OLMEDO, A.M., BLESA, M.A., IGLESIAS, A., KOENIG, P., J ournal of Nuclear Materials, 229, 1996, p. 79-92.

8. PIRVAN, I., RADULESCU, M., VELCIU, L., VISAN, T., Rev. Chim. (Bucharest), 49, no. 8, 1998, p. 561-566.

9. PIRVAN, I., RADULESCU, M., LUNCAN, D., VISAN, T., Rev. Chim. (Bucharest), 49, no. 10, 1998, p. 713-719.

10. COX, B., Journal of Nuclear Materials, 28, 1968, p. 1-47.

11. CHEN, Y., NIE, X., NORTHWOOD, D.O., Surface and Coatings Technology, 205, no. 6, 2010, p. 1774-1782.
12. MALINOVSCHI, V., MARIN, A., NEGREA, D., ANDREI, V., COACA, E., Materials Research Express, 4, 2017, Article 095702.

13. CHENG, Y., WU, F., MATYKINA, E., SKELDON, P., THOMPSON, G.E., Corrosion Science, 59, 2012, p. 307-315.

14. CHENG, Y., WU, F., DONG, J., WU, X., XUE, Z., MATYKINA, E., SKELDON, P., THOMPSON, G.E., Electrochimica Acta, 85, 2012, p. 2532.

15. CHENG, Y., MATYKINA, E., ARRABAL, R., SKELDON, P., THOMPSON, G.E., Surface and Coatings Technology, 206, no. 14, 2012, p. 32303239.

16. CHENG, Y., MATYKINA, E., SKELDON, P., THOMPSON, G., Electrochimica Acta, 56, no. 24, 2011, p. 8467-8476.

17. ZOU, Z., XUE, W., JIA, X., DU, J., WANG, R., WENG, L., Surface and Coatings Technology, 222, 2013, p. 62-67.

18. APELFELD, A.V., ASHMARIN, A.A., BORISOV, A.M., VINOGRADOV, A.V., SAVUSHKINA, S.V., SHMYTKOVA, E.A., Surface and Coatings Technology, 328, 2017, p. 513-517.

19. CHEN, Y., NIE, X., NORTHWOOD, D.O., WIT Trans. Eng. Sci. (Tribology and Design), 66, 2010, p. 183-194.

20. WANG, L., HU, X., NIE, X., Surface and Coatings Technology, 221, 2013, p. 150-157.

21. MALINOVSCHI, V., MARIN, A., MOGA, S., NEGREA, D., Surface and Coatings Technology, 253, 2014, p. 194-198.

22. TORAYA, H, YOSHIMURA, M., SOMIYA, S., Journal of American Ceramic Society, 67, no. 6, 1984, p. C119-C121.

Manuscript received: 4.04 .2018 